International Journal of Community and Cooperative Studies

Vol.8 No.1, pp.35-51, June 2020

Published by ECRTD- UK

ISSN 2057-2611(Print), ISSN 2057-262X(Online)

\title{
CHALLENGES AND PROSPECTS OF GOVERNMENT'S ROLE FOR COOPERATIVE DEVELOPMENT IN ETHIOPIA
}

\author{
Firehiwot Yemane Yehdego \\ Policy Studies Institute of Ethiopia
}

\begin{abstract}
This paper is conducted on the challenges and prospects of government's role for cooperative development in Ethiopia. It is intended to contribute in the process of directing such a role towards more sustainable and genuine cooperative movement. Cooperative legislation; secondary data from the federal cooperative agency and existing literature on the cooperative movement in the country constitute the major source of data for the study. Qualitative approach was adopted for analysis. The major services provided by the Ethiopian government for cooperatives include establishment of legal framework; provision of capacity building activities; institutional support at different administrative levels offering audit, inspection, organization and promotion activities; exemption from income tax; entitlement to obtain land for their operation. The challenges identified include violation of cooperative principles; provision of similar services to all types of cooperatives leading to inability to avail specialized services to peculiar types of cooperatives and limited effort made for inclusion of disadvantaged groups of the community; lack of awareness about cooperatives. The different government organs responsible for cooperative promotion should for future focus on conducting research to identify areas of improvement, recognize the need for respect for cooperative identity; direct cooperative efforts development toward maximizing benefit to members and equitable sharing among them so as to prepare them for self-sufficiency.
\end{abstract}

KEYWORDS: cooperative development, federal cooperative agency, cooperative promotion, autonomy and independence

\section{INTRODUCTION}

Cooperatives have existed for around two hundred years. (Borzaga \& Galera, 2012) Even though the notion of working together is as long as hunting and gathering. In some situation it is evolved as a completely self-help effort in the fight against exploitation of the poor and vulnerable. In others it was deliberately introduced form of organization by government to promote socio economic development. As is the case in most developing countries, cooperative development in Ethiopia is an example of the later. Since the introduction of cooperatives in such a way, different governments in Ethiopia have been an important partner for cooperative development in the country. While it is important to have government support for sustainable cooperative development, it has its set back when it is not done with caution. This paper is intended to assess the challenges and the prospects of the role government play for cooperative development in Ethiopia. 
Vol.8 No.1, pp.35-51, June 2020

Published by ECRTD- UK

ISSN 2057-2611(Print), ISSN 2057-262X(Online)

\section{Statement of the Problem}

The role of government to cooperative development in Ethiopia ranges from the establishment of legal framework to, in some cases, involvement in decision making and implementation of the same on issues regarding the day to day activities of cooperatives at different levels. Given the level of development in the country and the role cooperatives play in promoting such development, the need for government support to cooperatives seems to be unquestionable. Historical evidence demonstrates that compared with investor-owned enterprises, cooperative solutions are more inclusive and more oriented to promoting general interest goals with a beneficial impact on wellbeing. (Borzaga \& Galera, 2012) This makes it the agenda of the government to support cooperatives so as to facilitate sustainable and equitable development in the country. In addition to this, due to socio economic status of members coupled with accessibility and nature of services cooperatives need to receive from the government; arranging the services by the members themselves is difficult. Whilst such support is needed and being provided by the government of Ethiopia, it is not with our any apparent concerns. GSDRC (Governance and Social Development Resource Centre) asserts Cooperatives have limitations, and will thrive in supportive environments and struggle in others. (GSDRC, 2011) Wanyama, Develtere and Pollet recognized the relevance of government to cooperative development but it mostly ended up in violation of autonomous nature of cooperatives. (Wanyama, et al., 2009) But the issue of balancing between the provisions of such support services and compromising the autonomy cooperatives will have to be effectively addressed so that sustainable development of cooperatives can be a reality. Unless they have autonomy and independence from any sort of external interference, ultimately they suffer from loss of member control and democratic nature of cooperatives. Also, with the continuous provision of such services by the government cooperatives may end up developing dependency that will hamper the ability of cooperatives to in the long run be self-sufficient. Hence this paper will contribute in facilitating genuine cooperative development by assessing the different support services provided and the challenges existing.

\section{LITERATURE REVIEW}

\section{History of cooperatives in Ethiopia}

Although the existence of traditional forms of cooperation can be traced way back, the modern form of Cooperatives was introduced in Ethiopia by Emperor Haileselassie I in 1960. They were introduced by issuing the first cooperative legislation called Farm Workers Cooperative decree Number 44/1960. The objectives of issuing the decree and as a result establishment of cooperatives include solve marketing and transportation problems; manage agricultural machinery and livestock; and diversify modern agriculture. The government planned to establish 20 Cooperatives, but of these only 4 Cooperatives were formed. They were established to address unemployment, immigration from rural to urban and land tenure questions from different directions. Due to their limited number and scope, the impact and contribution they made in improving the lives of their members was negligible.

After the end of the imperial regime, the Derg (1974-1991) implemented socialist economic system until the eve of its downfall. With socialist economic system in place; cooperatives were 
given central role to play throughout the country. As a result large numbers of different kinds of cooperatives were established, but they were subject to interferences from the government.

According to the 1985/86 report of the Ministry of Agriculture (MOA), by (Tegegne, 1988) the total number of Peasant Associations (PAS) in Ethiopia by the end of June 1985 was 20,157 with a total membership of 5,594,018 households. Considering 4.4 people as the average size of households in the rural areas, the PAS contain 66 per cent of the total rural Ethiopian population using the 1984 census. These grass root peasant institutions became the basis for creating the various types of rural cooperative organizations.

About the end of its rule, Derg declared mixed economic system where members of cooperatives were given freedom to leave their societies if they decide to. This leads to large number of members voluntarily leaving their cooperatives, as a result of which many cooperatives lost their strength. Some literature shows the number of cooperatives reduced after the downfall of Derg as there was no attention given to them by the transitional government. In fact they were considered as instruments of the previous regime. Some affiliates of the current government even embezzled properties of cooperatives wrongly assuming that they were owned and run by the previous government.

By 1995 the FDRE (Federal Democratic Republic of Ethiopia) government issued agricultural cooperative proclamation number $85 / 1995$, which recognized the role of cooperatives for promoting economic development especially supporting the implementation of ADLI (Agricultural Development Led Industrialization) policy. Since then there has been steady growth in the number of cooperatives, their membership, their financial resources and types as well.

(Emana, 2009) Pointed out cooperative development in Ethiopia has been guided by a deliberate legislative framework namely Farm Workers Cooperative decree number 44/1960; Cooperative Proclamation Number 241/1966); Agricultural Cooperatives Proclamation Number 85/1995; Cooperative Society Proclamation Number 147/1998; Cooperatives' Commission Establishment Proclamation Number 274/2002.

Later in response to the changes in the country's, proclamation number 985/2016 is issued and implemented to replace Cooperative Societies Proclamation 147/1998. According to Cooperative Societies Proclamation Number985/2016, which is the current cooperative legislation, any type of cooperatives can be established by any group of 50 or more people who are interested and able to utilize cooperative services based on ICA (International Cooperative Alliance) cooperative principles and values. Despite different hurdles the movement has been facing, the growth of cooperatives; the role they play in the national economic development; and their future potential is undeniable. Hence it is profoundly important to assess the current status of cooperative development in the country as follows.

The statistics in federal cooperative agency's annual magazine number 13 shows the number of cooperatives; their size of membership and composition; their capital base as follows. Accordingly, there is no cooperative league in the country and there are 3 federations. 
International Journal of Community and Cooperative Studies

Vol.8 No.1, pp.35-51, June 2020

Published by ECRTD- UK

ISSN 2057-2611(Print), ISSN 2057-262X(Online)

Table 1. Number of cooperatives, their membership and unions in Ethiopia

\begin{tabular}{|l|l|l|l|l|l|l|}
\hline \multirow{2}{*}{ Year } & \multirow{2}{*}{$\begin{array}{l}\text { Primary } \\
\text { Cooperatives }\end{array}$} & Male & Female & Total & \begin{tabular}{l} 
Number of $\begin{array}{l}\text { Primary } \\
\text { cooperative } \\
\text { unions }\end{array}$ \\
\cline { 3 - 7 }
\end{tabular} & $\begin{array}{l}\text { Pooperatives } \\
\text { affiliated to unions }\end{array}$ \\
\hline 2010 & 38454 & 5458924 & 1322299 & 6781223 & 245 & 6792 \\
\hline 2011 & 43255 & 5153271 & 1413423 & 6566694 & 278 & 7843 \\
\hline 2012 & 48124 & 5109566 & 1525892 & 6635458 & 293 & 8431 \\
\hline 2013 & 56044 & 6949589 & 2215678 & 9165267 & 333 & 10179 \\
\hline 2014 & 71249 & 9425321 & 3374179 & 12799500 & 353 & 10662 \\
\hline 2015 & 74904 & 10216320 & 3846812 & 14063132 & 363 & 10816 \\
\hline \multicolumn{7}{|l|}{ Source: Federal cooperative agency annual magazine number 13} \\
\hline
\end{tabular}

By December 2015, the total capital primary cooperatives was 12,819,893,988 ETB (Ethiopian Birr) and cooperative unions had 3,533,540,322 ETB. The sectorial composition of primary and secondary level cooperatives show that the cooperative sector in the country is dominated by the agricultural cooperatives followed by saving and credit cooperatives. ICA (2013) concluded even though there are a number of issues and problems internally and externally cooperatives can be driving forces for promoting sustainable development. Also, the numbers of primary cooperatives which are members of cooperative unions show that the degree of vertical integration is not satisfactory.

Table 1. Number of cooperative in Ethiopia by type

\begin{tabular}{|l|l|l|l|}
\hline Type of cooperative & $\begin{array}{l}\text { Primary } \\
\text { cooperatives }\end{array}$ & $\begin{array}{l}\text { Cooperative } \\
\text { unions }\end{array}$ & $\begin{array}{l}\text { primary cooperatives } \\
\text { affiliated to unions }\end{array}$ \\
\hline Agricultural cooperatives & 22,379 & 202 & 4,823 \\
\hline Other non-agricultural cooperatives & 27,726 & - & - \\
\hline Saving and credit cooperatives & 18,527 & 115 & 5,091 \\
\hline Consumers cooperatives & 3,469 & 30 & 437 \\
\hline $\begin{array}{l}\text { Natural resources and Tourism } \\
\text { cooperatives }\end{array}$ & 1,060 & 7 & 106 \\
\hline Mining cooperatives & 1,337 & 9 & 240 \\
\hline Handicraft cooperatives & 406 & - & - \\
\hline Total & 74,904 & 363 & 10,697 \\
\hline
\end{tabular}

Source: Federal cooperative agency annual magazine number 13

\section{The need to support cooperatives by government}

Cooperatives are usually organizations of the poor and people of limited means, where they form cooperatives to improve their livelihood by pooling resources and engage in an activity of business nature with social relevance in it. In developing countries like Ethiopia, people joining cooperatives are those having little to no potential to access even the basic services; skills and experience and necessary linkages they need to run their cooperatives for different reasons. Then 
here comes an opportunity for government to involve in promoting and supporting them. The need for promoting cooperatives comes from the role cooperatives have to alleviate poverty, create employment opportunity either directly to employees or facilitating self-employment of their members, pool resources of members leading to expansion of business and economic activities, promote market oriented production and value addition, inculcate and develop the culture of working together for better life and social values simultaneously; ultimately leading to multidimensional societal transformation. Borzaga and Galera (2012) suggested knowing more about cooperatives requires realizing how the society benefits from them. In the sense it is made easier through careful analysis of their impact on the life of its members that can be reflected from different macro-economic data.

To invest in cooperative development is to invest in creating or strengthening sustainable businesses that have the potential for large scale impact when it comes to lifting households out of poverty, providing services to the underserved and protecting the economic assets of the poor. (OCDC, 2007) (Overseas Cooperative Development Council)

Dr Chiyoge B Sifa, Regional Director of ICA Africa Region, pointed out "The recognition of cooperatives as a crucial means for poverty alleviation and therefore African development has been widely acknowledged. It is for this reason that co-operatives have been promoted in virtually all African countries since the colonial period." (ICA, 2013).

Aregawi and Haileslasie (2013) stated ooperating in market; cooperatives enhance ability to affect market prices by pooling resources and are capable of retaining earnings for their constituents. This will fetch higher financial gains for member. By becoming members, not only members will get access to different goods and services; they also get to divide the profit made amongst themselves that they ended up in retaining earning that would have otherwise transferred to other market actors. This characteristic of cooperatives is also recognized by the government in Ethiopia. According to the sector development strategy for agriculture; the government of Ethiopia has identified cooperatives as a form of business organization which can facilitate strong socio economic development. (ATA, et al., 2012) .

Cooperatives have played significant role towards achieving the growth and poverty reduction strategy by promoting income generating activities and improving access to banking services to rural and urban households. (Kifle, 2015) Such growth and poverty reduction activities have been at the centre of every development plan in the country for the last quarter of the century. Hence not only cooperatives need the support but it is in the government's development agenda to support them. Because creating and maintaining favourable environment for cooperative development will definitely have contribution to achieve overall development goal of Ethiopia. What make such role of cooperatives more attractive is growth and poverty impacts they induce are mostly long term and sustainable. According to Borzaga and Galera (2012) cooperatice societies are capable of bringing growing amount of finance and jobs in a number places. Wanyama, Develtere and Pollet (2009) also concluded this and other roles of cooperatives are deriving factors making governments and other development partners in the third world put efforts towards cooperative establishment and expansion. Such kind of role cooperatives play is especially important when they provide services that members cannot have access to otherwise like financial services in rural 
areas. Borzaga and Galera (2012) further recognized cooperatives as "social actors" emphasizing their roles in continiously solving challenges faced by people around their area of operation. This role of cooperatives actually is one of the cooperatives principles namely "concern for community". It explained the responsibility cooperatives have towards the community surrounding them in addition to the reponsibility to their members. They are expected to make a number of contributions to the community ranging from extending access to the different services they provide to members of the community to availing different infrastructure facilities at their expense if the general assembly decides to do so.

One of the most important social roles cooperatives play has been acting as a platform for underprivileged sections of a community, including women, young people and people with disabilities, in their day to day functioning. Tesfaye and Tadele (2013) added that cooperatives can be used as breeding grounds to empower women by enhancing their specific knowledge and capacities. Empowerment of people by cooperatives has long been recognized by the government especially among poor rural farmers, women and other disadvantaged groups. The government of Ethiopia recognizes and supports multi-purpose cooperatives to actively participate in the development process towards employment and women empowerment. (Aregawi \& Haileslasie, 2013) Multipurpose cooperatives are organized by farmers, who live in same region, in Ethiopia. They provide their members with different kinds of agricultural inputs; they market agricultural outputs of members on behalf of them; they arrange credit services as main functions besides the socio economic and community roles they play. In the process of performing their main activities; they also involve in empowerment of their members including women youth and other under privileged groups through training, experience sharing programs and acting as a platform to make their voice heard.

The formation of cohesive groups of farmers in the form of farmer cooperatives is a very effective means of empowering people and making things happen in favour of the poor. (Rogers, et al., 2008) For example small holder farmers in Ethiopia have little to none financial services accessible to them from formal financial sector and institutions like commercial banks. But the relevance of access to credit and financial services for investments that improve agricultural productivity is undebatable. The only way for a farmer to access services of such kind is becoming a member of multi-purpose agricultural cooperative society; the same is true for access to credit, grading and standardization services, marketing and bargaining services.

As institutions of business as well as social nature, they can contribute to create harmonious relationship among members of a community through mutual respect and solidarity. As it is pointed out Cooperatives are also sometimes seen as beneficial for conflict resolution, peace building and social cohesion. (GSDRC, 2011) As they are organized, owned and run by people residing in common geographic location; they can strengthen mutual respect among community members. In addition to this cooperatives are institutions that should treat every member equally without discrimination of any kind; such a motto will enhance better social inclusion and relationship. It is rightly pointed out the social impact of cooperatives is more than an additional feature or an externality: it is an added value that is voluntarily generated and is an integral part of the operation of cooperatives. (Borzaga \& Galera, 2012) Promotion and support for cooperative 
Vol.8 No.1, pp.35-51, June 2020

Published by ECRTD- UK

ISSN 2057-2611(Print), ISSN 2057-262X(Online)

development should also give enough weight to enabling cooperatives realize their social goals for their members and form the community and the country at large as well.

Facilitating the provision of services mostly those services private sector doesn't provide or those not provided otherwise is also one of the necessities that make support to cooperatives worth investing in by government and other stakeholders. According to OCDC (2007) youth cooperatives can play an integral role in developing countries' overall economic development plans, especially as developing countries look to provide sustainable economic livelihoods for the unprecedented number of youth about to enter the labour force Given the institutional characteristics of cooperatives as they are organized, owned, managed and serve people of limited means, they need external support from government to thrive. Especially when it is about different services they are not capable of arranging by themselves. For example OCDC (2007) the no availability of finance can be a huge problem for cooperatives to strengthen their business activities.

\section{METHODOLOGY}

This paper is conducted based predominantly on the analysis and review of existing cooperative legislation in Ethiopia, secondary data from federal cooperative agency on the status of cooperatives and different support services government provide for cooperatives and other literature on cooperative movement and development in the country. In depth analysis of the issues regarding the challenges and future prospects of governments' contribution to cooperative development is conducted.

\section{RESULT AND DISCUSSION}

\section{Government's role for cooperative development in Ethiopia}

Historically the issue of whether or not government has a role in cooperative development has never been a question in Ethiopia. This is because of the recognition given to the relevance of cooperatives as a galvanizing force for mobilizing people and resources to promote socio economic development in the country. Hence all the three regimes have been providing support to the sector since the 1960s, although they had different approaches. This role can be summarized in to establishment of legal framework, capacity building, and the provision of extension services, creating linkages and research and knowledge sharing.

Establishment of legal framework has been the first and major form of support Ethiopian governments have been providing for cooperative development. It has also been the main entry point to establish relations between cooperatives and government throughout since the introduction of modern cooperatives in the country.

During the reign of Emperor Haile Selassie I, Farm Workers Cooperative decree number 44/1960 was issued. Later, it is replaced for shortcomings by legislation named Cooperative society 
Vol.8 No.1, pp.35-51, June 2020

Published by ECRTD- UK

ISSN 2057-2611(Print), ISSN 2057-262X(Online)

Proclamation Number 241/1966. Tefera, et al., (2017) concluded most sources agree that during the Imperial era, co-operatives were fairly limited in scope and experience. (Tefera, et al., 2017) The Derg regime (1974-1991) introduced proclamation Number 71/1975 to promote farmers associations. With socialist economic system in place, Promotion of farmers association was not enough. Realizing this, Derg issued Cooperative Societies Proclamation NumberNumber $138 / 1978$ for the promotion and inclusion of other types of cooperatives.

After the downfall of Derg in 1991 the current government took a while to issue Agricultural Cooperative Societies Proclamation NumberNumber 85/1994; where the introduction of agricultural cooperatives was given more attention and urgency. The only type of cooperatives allowed legal existence is agricultural ones but this proclamation opened up a room not only for the organization of new agricultural cooperatives but also reorganization of previously organized cooperatives during the Derg regime. The rationale behind such urgency and attention to only agricultural cooperatives was adoption of ADLI policy that put transformation of the agriculture sector through modernization. Such modernization was planned to be achieved through introduction of modern agricultural production methods through different mechanisms; one of which is agricultural cooperatives as they are closest to farmers than any other means.

After the transition years, the federal government of Ethiopia recognized the importance of cooperatives for improving the socio-economic conditions of the rural poor. (Tefera, et al., 2017) Understanding the need for promotion of other types of cooperatives, the Ethiopian government again enacted a new legislation namely Cooperative Society's Proclamation Number 147/1998. This proclamation is issued on the basis of cooperative principles and values. It was also well developed legal document relative to the previous ones.

Later, Cooperative Societies (amendment) Proclamation Number 402/ 2004 and Cooperative Commission Establishment Proclamation 274/2002 became important legal documents in the cooperative movement of the country. Such introduction of legal framework is an important step towards the development of cooperatives, since it is the precondition for the very basic legal existence and recognition of cooperatives. This is also confirmed in the sector Development Strategy 2012-2016 as such the government of Ethiopia has paved the way for improved cooperative development in the country through the creation of a legal platform and the expansion of human resources development at higher institution levels. (ATA, et al., 2012) This was the case for other African countries as well. Consistent with the new economic environment that was sweeping across Africa in the 1990s, many countries introduced new policies and legislations ostensibly to liberalize the cooperative sector. (Wanyama, et al., 2009) Such legislation clearly defines role and responsibilities of every stakeholder. This will help to monitor and evaluate activities but most importantly it enables cooperatives to as much as possible maintain appropriate relationships with outsiders.

The present cooperative legal framework not only recognizes cooperatives role in the socio economic development of the country but also entitles them to special privileges and different services to be provided by the government as is stated in the proclamation. 
Vol.8 No.1, pp.35-51, June 2020

Published by ECRTD- UK

ISSN 2057-2611(Print), ISSN 2057-262X(Online)

Different capacity building activities have also been part of the support government provided to the cooperative sector. It ranges from strengthening the institutional support system through establishing and strengthening capacity of cooperative promotion offices at different levels to the provision of different services to cooperatives at different levels. The Government established federal and regional cooperative institutions that facilitate the organization of cooperatives. (Emana, 2009) Regional cooperative promotion offices in turn are endowed with the responsibility to strengthen zonal cooperative promotion offices, which in turn are responsible for district level cooperative promotion offices. With such responsibility comes along authority where evaluation, monitoring and supervision activities are given to apex level offices. To put it in a nut shell, cooperative promotion structures are established at regional, zonal and district levels. In some regions a cooperative professional is available at village level.

Article 43 of Cooperative Societies Proclamation NumberNumber 985/2016 specifies the types of government assistance cooperatives are to obtain from federal and regional cooperative promotion offices. Such services include exemption from income tax; entitlement to obtain land for their operation; receipt of promotion service and training from a national cooperative training institute; and exemptions from any court fees for primary cooperatives.

Cooperative Societies Proclamation NumberNumber 985/2016 articles 50 states "the appropriate authority shall audit or causes to be audited by a person assigned by it, the accounts of any society at least once in a year." As for inspection article 51 states "the appropriate authority may make an inspection of any cooperative society's organizational status, operations, documents and financial conditions as requested by the majority of the executive committee or one third of the total members or their representatives"

One of the seven ICA principles of cooperatives, cooperation among cooperatives, emphasizes that cooperatives can better serve their members when they can manage to work together at different institutional levels. This is in fact is more called for in countries like Ethiopia where majority of cooperatives are not strong enough to compete in market with private traders. Borzaga and Galera (2012) highlighted this fact arguing an effort to strengthen networking practices would help cooperatives achieve economies of scale and take advantage of growth opportunities that single enterprises would not otherwise be able to exploit. (Borzaga \& Galera, 2012) To this end the FCA (Federal Cooperative Agency) and its affiliates at different levels have been performing a number of activities to strengthen such vertical and horizontal integration between cooperatives. An example of such effort is breweries and malting factories are sourcing malt barley through developing value chain agreements with primary co-operatives and unions. In addition, woreda officials and NGOs are involved in the agreement to provide technical assistance, credit and other services. Through such a public-private partnership, the coordination problems present in value chain upgrading can be solved as each partner provides a part of the complementary services. (Tefera, et al., 2017).

The FCA not only provides different services to cooperatives through its affiliates but also facilitates provision of the same by different stakeholders supporting the cooperative sector in the country.Currently, resources are limited and international cooperative development research tends 
to be a secondary area of emphasis under studies on civil society, NGOs, farmer associations, rural participation, democracy and poverty alleviation. (OCDC, 2007) Though limited; FCA has been taking the lead in strengthening national cooperative research, capacity building and training activities by working together with colleges and universities offering different programs in the field of cooperatives, creating different platforms for discussion on the different issues regarding cooperative development in the country like organizing workshops on national cooperative day, publishing annual cooperative magazine, collecting and maintaining national data on cooperatives and their activities. There are at least 10 universities offering different cooperative education, training and community services activities.

\section{Challenges of government's role for cooperative development in Ethiopia}

Cooperatives have limitations, and will thrive in supportive environments and struggle in others. (GSDRC, 2011) Starting from 1994, the government designed various policies to strengthen the development and operation of co-operatives. (Tefera, et al., 2017) The government of Ethiopia follows a supportive policy towards cooperative development; but the extent of support provided for cooperatives is still not satisfactory. Since Ethiopia is a developing country, it is basically impossible to avail each and every service cooperatives need to get although mostly is worth investing in.

The foremost challenge has been creating and maintaining supportive environment for cooperative development without compromising their democratic and autonomous nature. It has been recognized that although cooperatives are more successful if they are initiated, organized and run by members themselves; in many cases they become externally introduced institutions by the government and non-governmental institutions due to different factors including lack of awareness about cooperatives and their workings by the people and vested interest from the government to utilize them as tools to implement national plans and goals. KWAPONG and HANISCH (2013) argue that organization of cooperative voluntarily by members is often violated; and they tend to be introduced to members by government. This is in against of cooperative principles that will create serious problems later on the movement.

This happens when government and other stakeholders engage in promoting cooperatives to primarily serve their own agenda. In such instances cooperatives fail to serve the needs of their members and become parastatal institution of such stakeholder. This in turn takes members rights and duties to decision making, management and monitoring. These functions will be performed by external parties; leading to lose of members sense of ownership. Wanyama, Develtere and Pollet (2009) added when cooperatives are organized by the "government"; they by default become pseudo acting as parastatal institution representing the same. Cooperatives were seen more as policy tools for reaching the poor and achieving national objectives than as member-owned and member-controlled organizations targeted for members' benefit. (KWAPONG \& HANISCH, 2013) A typical case of such a challenge can be Ethiopia, where article 23 of Cooperative Societies Proclamation Number 985/2016 states cooperatives will avail products and services to nonmembers on contract basis for the purpose of achieving the goals of government and development partners. 
GSDRC(2011) brought another perspective to this questioning the ability of cooperatives to pursue their objectives of different kind when they are established by government for the people that people organizing cooperative for improving their own life. The intention of the promoters of cooperatives here focused on priorities of national development rather than on the interests of the individual members and their needs. Cooperatives were conceived primarily as instruments of government for carrying out plans made by Government officials, financed with government funds and accordingly government controlled. (Munkner, 1988) But the problem is made worse when instead of getting the poor access to services of cooperatives; those members who are active and aware enough will be able to get larger shares of cooperative benefit. Then the principle of cooperative emphasizing equitable distribution of cooperatives benefits will be violated.

According to Kifle (2015) the capacity of FCA and regional cooperative promotion agency/ bureaus to effectively promote, regulate and supervise cooperatives is severely constrained by the absence of separate specialized units at the federal, regional and districts levels in charge of different type of cooperatives; and limited mobility of staff due to shortage of vehicles and motorbike and high costs associated. (Kifle, 2015) Making this to be even more difficult is increasing number of cooperatives from time to time while the capacity of the cooperative promotion office is still not enough as is emphasized the rapid expansion of the sector far out stripped the capacity of the government cooperative officers to manage the supervisory work. (Wanyama, et al., 2009) Such constraint in capacity is especially worse in the areas of audit and inspection that according to FCA during GTP-I (Growth and Transformation Plan-I) the plan was to inspect 171,139 primary cooperatives and 1,398 cooperative unions and 12 cooperative federations then 100,096 primary cooperatives, 1,379 cooperatives unions, and 5 cooperative federations were inspected. Whereas it was planned to audit for 197,410 primary cooperatives, 1,476 cooperative unions and 12 cooperative federations and 80,622 primary cooperatives, 1,087 cooperative unions and 5 cooperative federations have got audit services. (FCA, 2016).

The existence of strong legal system and supportive government policy is significantly important for cooperative development in general, but as is remarked by Borzaga and Galera (2012) Indeed, policies supporting cooperatives are often weak, contradictory, or controversial. (Borzaga \& Galera, 2012) In article 45 of Cooperative Societies Proclamation NumberNo.985/2016 it determines the amount to be kept as reserve fund, for expansion of business activities and social purposes $30 \%$ of net profit. The amount allocated for the reserve fund shall not exceed $30 \%$ of the capital of the society and it shall be deposited in the saving account of the society." But it doesn't say anything if it exceeds $30 \%$ of their capital, where a number of cooperatives have been facing different issues related to this including confusions as to how to utilize such exceeding. Munkner (1988) explains the models of organization were (and still are) predetermined in almost every detail (e.g. model by-laws are prescribed from which people are not supposed to deviate), government intervention and government control left (and still leaves) no room and no incentive for active participation by cooperative members. (Munkner, 1988).

A lack of public understanding about the role and impact of cooperatives on well-being ... Moreover, education about cooperatives is either limited or lacking in most public and private educational programs. (Borzaga \& Galera, 2012) This has been an issue since the very introduction 
of cooperatives in modern form in Ethiopia. Not a few members of cooperatives perceive that cooperatives are institutions of the government established to distribute different public services to the people due mainly to historical image cooperatives have in the country. The impact that such lack of awareness and understanding of cooperatives have on cooperative movement is witnessed right after the over throw of Derg regime. During this time cooperative were totally abandoned by not only a failing government but also by their own members because majority of the people assumed that cooperatives were representative of government institutions as the government had the upper hand in running them. Their resources were heavily embezzled and they ceased to exist without even proper audit, inspection and resource distribution. Kifle (2015) added to this issue stating it created a lasting suspicion and distrust of cooperatives, the stigma of which is haunting cooperatives until today. (Kifle, 2015) (BORZAGA \& GALERA, 2014) noted lack of awareness about cooperative ideology and little effort to create it even undermines the principles of decision making and voting in cooperatives; emphasizing that this principles are bedrocks for cooperative operations.

Cooperative Societies Proclamation Number 985/2016 in article 8 stipulates cooperative societies can be established in either production or service or both including professional cooperatives as far as it is not in areas prohibited by law, immoral to public values, activities affecting environmental security. This in itself if positive for cooperative development, but the government of Ethiopia in its plans, programs, and regulations intends to provide similar type of support services to all of them; which can be challenging for cooperatives in need of unique support especially cooperatives at apex level.

For a long period of time development planners considered cooperatives to be the only genuine form of organized self-help, while these alternative forms of self-help organizations were largely ignored. (Munkner, 1988) This recognition, however, has not yet translated into policies and programs in the cooperative sub-sector that are effectively facilitating women's increased and meaningful participation in these formal groups. (Thomas, et al., 2015) Looking at the size of women members, their participation in different committees and decision making positions; it is easy to understand the existing gender gap in participation of members of cooperatives. But so far except for some efforts the and there to minimize such gap, there are no specific policies or regulations to promote gender equality in cooperatives. This is the case not only for women but also for youth as well. Even if the demographic composition of Ethiopia shows large proportion of young people; there not real effort made to admit them as member or to cater to the demands of young people through cooperatives. But without such future orientated intervention, development of cooperative movement in Ethiopia in a sustainable manner is going to face challenges.

\section{Future prospects}

Cooperative development is an ongoing process. (Borzaga \& Galera, 2012) It calls for continuous improvement, research and support as lessons are being learned, errors are rectified and mitigation measures are taken as required.

The government of Ethiopia, for the sake of utilizing the potential role of cooperatives in serving the needs of their members and promoting socio economic development in the country, should develop a support system to enable them thrive in the changing environment. They should seek to 
strengthen systems that are already productive, rather than installing new institutions or procedures. (GSDRC, 2011) For this to happen, focus areas for future promotion and support activities are summarized in the following paragraphs.

OCDC (2007) recognized the need to study what constitutes favourable conditions for development of cooperatives considering how well developed and thought about are cooperative regulations. It also recognized the intention of studying specific conditions given the circumstances is to make it better for future sustainable cooperative development. Hence it necessitates exploring the current situation before proceeding with any effort. This can be done through research and development activities about different services cooperatives need from the government that should be conducted by cooperative promotion offices at all levels, educational institutions, NGO's separately or in collaboration. Whereas the future of cooperative development in a liberalized economic environment seems to be bright, the challenge is how to inculcate the business virtues in the less-adapted cooperatives in order to spread the benefits of the 'new' mode of cooperation to a wider population on the continent. (Wanyama, et al., 2009) For this to happen well-developed support system and specific support services are important to be kept provided and improvements on existing systems are very important in response to findings of different research and development activities. In addition conducting research and development isn't enough in itself unless the results are available to the concerned parties at all levels. To achieve this; it is very important to create platforms for continuous dialogue between government organs and cooperatives and their members. Such dialogue will help in identifying better ways to assess support areas for cooperatives without affecting the primary purpose of cooperatives. It is also important to provide continuous training on cooperatives and their institutional characteristics to every stakeholder.

Next to this comes the issue of enabling cooperatives to contribute to economic and societal transformation in Ethiopia or at least for their members as much as possible. GSDRC (2011) claims to achieve maximum possible contribution of cooperative for multi faceted societal transformation; supporting cooperatives while respecting cooperative identity and maintaing their independence from external interference is a precondition. This implies that mere organization of cooperatives isn't a guarantee for them to contribute to socio economic development. Rather respect for cooperative identity and philosophy is equally important for cooperative development. To this end, the government of Ethiopia therefore has to continue provision of promotion and development activities for cooperatives at different levels; and in response to changes in the service needs of cooperatives and changes in the external environment continuous improvements are called for.

The main content of the resultant framework was to facilitate the creation of commercially autonomous and member-based cooperative organizations that would be democratically and professionally managed, self-controlled and self-reliant. (Wanyama, et al., 2009) To this end GSDRC (2011) added priotiy should be given to serving their members before they start to plan about the community in general.This is conditioning such cooperatives to function as demanddriven and market-oriented business organizations, thereby remaining in tandem with the forces of liberalization. (Wanyama, et al., 2009) Unless they are capable of serving the needs of their 
International Journal of Community and Cooperative Studies

Vol.8 No.1, pp.35-51, June 2020

Published by ECRTD- UK

ISSN 2057-2611(Print), ISSN 2057-262X(Online)

members with business orientations, their very existence is questionable. Hence the government of Ethiopia should primarily assist the process of servicing the needs of cooperative members.

The quality and quantity provided by many cooperatives fall short of the needs and expectations of their members and other farmers. (ATA, et al., 2012) Development and introduction of service standards and grades for products provided by cooperatives in the future could be guided towards for the sake of improving member's satisfaction and maintain their sense of ownership and commitment. Related to this is making sure the services and products provided by cooperatives are reaching to all the members and especially weaker sections of the community like women, people with disabilities, poor rural youth etc. The poor had seldom been reached by the cooperative programs under review (Wanyama, et al., 2009) An effort must be geared towards ensuring such equality of access to and quality of cooperative services. Experiences of such efforts should be made shared for other cooperatives through different platforms. Wanyama, Develtere and Pollet further added that in response to members requirments; cooperatives are adding more and more functions rather than focusing on just a single one; but such cooperatives are not many in number. As owners, managers and users of the cooperative services, the knowledge of cooperatives and their functioning is a very important ingredient for success of cooperatives so that they become capable of exercising their rights and taking care of their responsibilities. A stronger awareness by members about the intrinsic features of cooperative enterprises should be encouraged. (Borzaga \& Galera, 2012) To achieve this, different programs can be arranged by cooperatives themselves or different offices supporting cooperatives. Training and education, short courses for cooperative staff and members should be systematized, and delivered by cooperative colleges to make them less donor dependent. (GSDRC, 2011) But such education and training should be extended to people and stakeholders outside the cooperative movement. In order to ensure appropriate delivery and maximum outcome; the responsibility to arrange and organize such programs should be the federal cooperative agency and its affiliates and cooperatives themselves. Cooperative movements should endeavour to raise awareness by public administrations, policymakers, and communities about the contributions of cooperatives to local economies and welfare systems. (Borzaga \& Galera, 2012).

The fact that cooperatives are on the receiving side of support services for so long will ultimately make them open up rooms for external interference. Dependence on governments or donors restricts growth, allows outside control and reduces autonomy, commitment and participation of members. (OCDC, 2007) A number of measures can be taken to alleviate this problem ranging from provision of support services based on clearly defined preconditions to facilitating conditions for such services to be provided in market. While providing for legitimate tax breaks and special benefits, cooperative legislation should include specific obligations for cooperatives to prevent demutualization, such as asset lock rules. (Borzaga \& Galera, 2012) Such arrangements can be considered as on payment services where cooperatives can retain at least some level of their autonomy and independence. Building capacity of cooperatives to enable them gradually become self-reliant and developing a system where the private sector can provide those services in exchange for a payment just like any other services in other sectors. 
As much as it is important for cooperative development to have the support from the government; it is equally important to have continuous improvements with up to date information and understanding about the state and status of cooperatives. As it is rightly pointed out to understand the cooperative movement, a realistic estimation of the overall size of the cooperative sector is needed. (Borzaga \& Galera, 2012) Hence the FCA, regional, zonal and district cooperative promotion offices can work on gathering, maintaining and continuously update data on different issues regarding cooperatives including but not limited to their type, membership composition and size, geographic location, financial base, level of members participation, strength of their management. Borzaga and Galera (2012) further asserted most places don't have full-fledged and recent information on different aspects of respective cooperative movements and what is there is "unsatisfactory". Such an effort can be made more effective by doing it in collaboration with the cooperative research and training systems. Colleges and universities offering programs on cooperative studies should take the upper hand in doing so. Such reliable and satisfactory data is also helpful in assisting education training and community services.

Although the government of Ethiopia intends to provide support services to all cooperatives; the ability different cooperatives have to make use of such support is different. To this end an effort to enable them be able to use the services is an important step towards promoting cooperatives. Wanyama, Develtere and Pollet (2009) also concluded that presence of strong membership base with vibrant management committee are capable of making use of support services than other. Hence more emphasis should be given to relatively weaker cooperatives. One measure can be disaggregating cooperatives based their financial, physical and human resources they have at hand and make an appropriate level of support that match their characteristics. The criteria for disaggregating can mainly be based on their services needs but also can include geographic location, types of activity performed, membership composition, amount of capital owned and capacity to pay for some services. To this end cooperatives in rural parts of the country mostly need awareness creation programs on cooperative philosophy, on areas of members involvement whereas cooperatives involved in marketing activities may need market integration more than other services.

Strengthening cooperation among cooperatives to facilitate exchange of services and experiences amongst themselves is another future area of support for government of Ethiopia to provide for strong and vibrant cooperative development. Such integration must be multi-faceted in the form of market integration, financial support and credit service provision, information and experience sharing between and among cooperatives and with other institutions working with the cooperative sector. Borzaga and Galera in 2012 suggested such an integration is to be done by "both national and local governments and cooperative movement" between places with different levels of cooperative development.

\section{CONCLUSION}

In Ethiopia the role of government in the promotion and development of cooperatives will definitely be needed for a while at least to a point where cooperatives are self-sufficient and selfreliant enough to arrange and afford the different support services being provided by government 
on their own. The jackpot is finding the right balance of support to make sure they are getting the services they need now to stay in business, play as much socio economic role as possible and while making sure they are not developing sense of dependence and inefficiency which might ultimately lead to loss of cooperative identity. At the end of the day they also have social responsibility for their community as well besides serving the needs of their members.

The results of this study showed that the government of Ethiopia has supportive policy towards cooperative development through establishment of legal framework; entitlement of cooperatives for different services, creation of linkages between different stakeholders; conducting and facilitating research and development activities. In doing so the major challenges among others include inability to provide support to an increasing number of cooperatives due to lack of enough capacity at FCA and its affiliates; in instances undesired interferences in the activities of cooperatives which compromises the autonomy of cooperatives; gaps in policies and regulations; lack of enough awareness about cooperatives and their activities due to lack of information and bad image of cooperatives as a result of previous experiences.

Strengthening existing support systems, continuous improvements based on the research findings; taking measures to balance between the role of cooperatives to their members which is the primary purpose for their existence and the socio economic role they have to national goals and plans; strengthening awareness creation programs; support the process of cooperative capacity building to gradually enable them avail services they receive from the government and reduce the chances of them being dependent forever; collecting and maintain data on cooperatives for training, research and development; facilitating collaboration between cooperative sector.

To put it in a nutshell; the role of Ethiopian government to cooperative development is not an issue of argument; it is relevant and needed. But it should be made without compromising the autonomous nature of cooperatives and in a sustainable way that will not make them a reflection of government performance.

\section{IMPLICATION TO RESEARCH AND PRACTICE}

Future research in this areas can focus on the identification of different services needed by different types of cooperatives peculiar to their activities; the impact of such support on the performance of cooperatives and the potential of cooperatives to afford the services they need-probability.

\section{References}

Aregawi, T. and Haileslasie, T., 2013. The role of cooperatives in promoting socio economic empowerment of women:evidence from multi purpose cooperatives societies in south eastern zone of Tigray, Ethiopia. International Journal of Community Development.

ATA, FCA and FDRE, 2012. Agricultural Cooperatives Sector Development Strategy 2012-2016. Addis Ababa: s.n.

Borzaga, C. and Galera, G., 2012. Promoting the Understanding of Cooperatives for a Better World. Euricse contribution to the International Year of Cooperatives, Trento: Euricse. 
Vol.8 No.1, pp.35-51, June 2020

Published by ECRTD- UK

ISSN 2057-2611(Print), ISSN 2057-262X(Online)

BORZAGA, C. and GALERA, G., 2014. The potential of social economy for local development in Africa: an exploratory report, Brussels: European Union, Policy Department DG External Policies.

Emana, B., 2009. Cooperatives : a path to economic and social empowerment in Ethiopia. Dare Salaam: ILO.

FCA, 2016. Annual magazine, Addis Ababa: FCA.

GSDRC, 2011. Helpdesk Research Report: Cooperatives and development, s.1.: governance and social development resource center.

ICA, 2013. Africa Cooperative Development Strategy;cooperative Entreprises build a better world, Nairobi: ICA Africa Region.

Kifle, T., 2015. Cooperative Movement in Ethiopia: Development, Challenges and proposed intervention. Journal of Economics and Sustainable Development.

KWAPONG, N. A. and HANISCH, M., 2013. Cooperatives and Poverty Reduction: A Literature Review. Journal of Rural Cooperation, 41(02), p. 114-146.

Munkner, H., 1988. Consequences of Self-Help promotion for cooperative development policy in Africa. In: Cooperative revisited. Uppsala : Scandinavian Institute of African Studies, pp. 187-206.

OCDC, 2007. Cooperatives:Pathways to Economic,Democratic and Social Development in the Global Economy. Arlington: s.n.

Rogers, P. P., Jalal, K. F. and Boyd, J. A. .., 2008. An Introduction to Sustainable Development. London: Glen Educational Foundation, Inc ..

Tefera, D. A., Bijman, J. and Slingerland, M. A., 2017. Agricultural Cooperatives in Ethiopia; Evolution, Functions and Impact. Journal of International Development, pp. 431-451.

Tegegne, T., 1988. The state and rural cooperative in Ethiopia. In: Cooperative revisited. Uppsala: The Scandinavian Instiutet of African Studies, pp. 125-138.

Thomas, W., F. T. and Waller, M.-K., 2015. Women's Participation in Agricultural Cooperatives in Ethiopia. Milan, Italy, s.n.

Wanyama, F. O., Develtere, P. and Pollet, I., 2009. Reinventing the wheel? African Cooperatives in a liberalized economic environment. Annals of Public and Cooperative Economics, September, 80(3). 